\title{
B 3421960
}

\section{TH E}

LOCKED

CASE

\section{N A TURALIST.}

\section{NUMBER 1 .}

\section{NATURAL HISTORY}

O F

MAMIALIA, BIRDS, FISHES, BUTTERFLIES, SHELLS, REPTILES, FLOWERS, FRUITS, PLANTS, \&C.

ILLUSTRATED BY FIVE PLATES, ENGRAVED ON STEEL, AND BEAUTIFULLY COLORED.

P.UBLISHED BY

FERDINÁND QUARRÉ,

NEW YORK.

- $78.1 .6 \ldots \times 5$

1844 .

PRICE, 50 Cents a Single Number. $\$ 5.00$ for Twelve Copies. $\$ 5,00$ in advance for the Subscription of Twelve Numbers. 


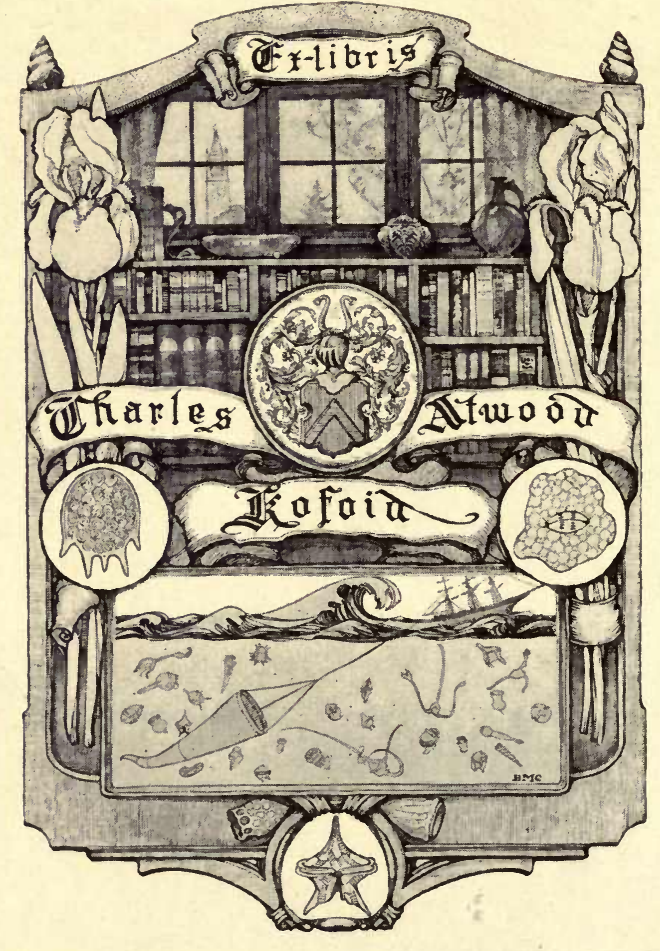




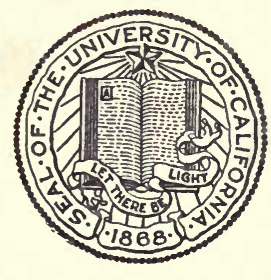

THE LIBRARY OF THE UNIVERSITY OF CALIFORNIA

PRESENTED BY PROF. CHARLES A. KOFOID AND MRS. PRUDENCE W. KOFOID 



\section{INTRODUCTION.}

Natural History offers to our study and observation many inducements, the greater as they are in a measure promoted at every moment, by the objects surrounding us. What science, in fact, can claim more interest and awaken our curiosity to a higher degree, than the one which acquaints us with the animated beings that breathe with us on the earth! Which makes us follow the feathered tribes through the air, or fathom the waters in search of their innumerable inhabitants.

How pleasing and interesting it is to follow in our gardens the study of flowers, plants and fruits; to class their different families, to divide their numerous species, to know, to aid their culture, vegetation and reproduction!

And in observing the wonders of nature in these productions, how much do we not feel we must admire and adore the wisdom and divine bounty of an Almighty God, who has created all; whose Providence is displayed as fully in the basest insect or plant, as in the most stupendous phenomena of the Universe.

.The study of Natural History, although the most true, the most simple, and interesting of all studies, is nevertheless the one most neglected. Even its votaries are satisfied with selecting one of its numerous branches, seemingly forgetting all the others; thus, some study the History of Birds, others of Butterflies, others of Flowers, and others, of Shells; and yet, among these, there are some whose researches do not go beyond a few species; thus, an amateur of Tulips, will feign to be ignorant of the existence of other flowers; some amateurs of Birds, will only observe Parrots; or notice but one species of the innumerable families forming the ensemble of the great works of creation.

One obstacle to the more general diffusion of a knowledge of the different species forming the vegetable and animal kingdoms, is the high price required of the works, and their too voluminous collection.

To obviate this inconvenience, we offer to our subscribers the Naturalist, arranged and classified, so as to form a complete natural history of each species.

This History will be continued in the same order in all the following numbers.

Exact and correct description will afford ample knowledge of each animal or plant; of its origin, usefulness, habits, or of its specific properties.

Five plates will be engraved on steel, and will be colored with the greatest care and faithfulness.

For each number the drawings will be executed from the very best works extant, and frequently from Nature.

This publication, which, in the course of one year, will give the description and fac simile of more than 75 Birds, 75 Mammalia, of as many Butterflies, Fishes, Shells, Reptiles, Insects, Flowers, Fruits, and Plants of every description, will be sold at the following low rate :

For each number colored with the greatest care, - _ _ _ _ $\quad$ - 50 cents.

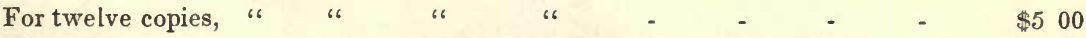

Subscriptions for twelve numbers will be received for $\$ 5$, paid in advance.

By these means, this great study of Nature, published at so moderate a price, will be placed within the reach of all intellects, and the interest afforded in each number, by its diversity, will but elucidate its exposition, and the details of scientific description.

Orders must be directed, postage paid, to

FERDINAND QUARRE, Publisher of the Naturalist, New York.

N. B. All papers inserting this prospectus in their columns, will be entitled to one year's subscription. 


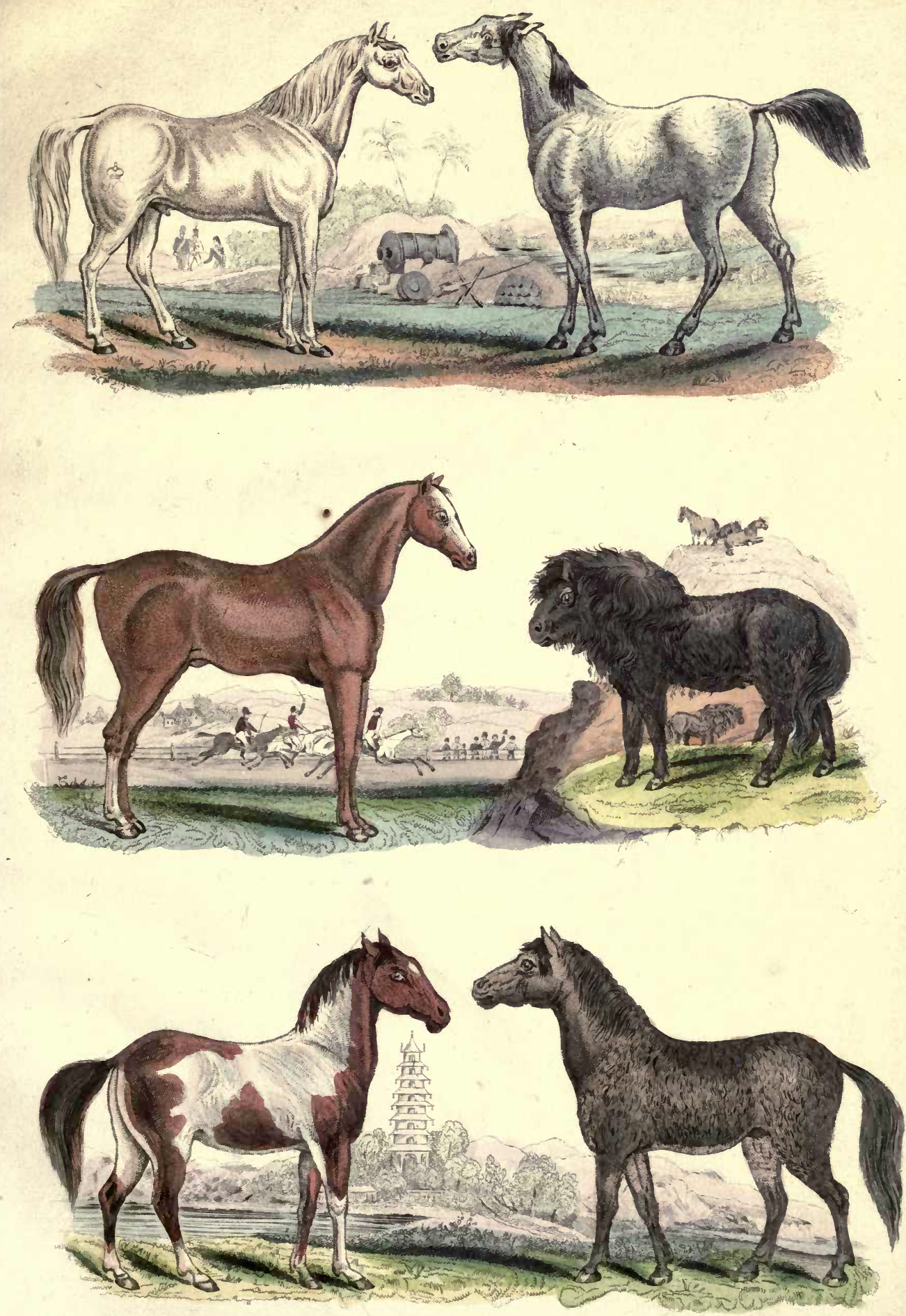



\section{THE NATURALIST.}

\section{MAMMALIA.}

\section{NATURAL HISTORY OF QUADRUPEDS.}

THE EQUID正 IN GENERAL.

In the structure of the whole Equine family, we find slight differences in size and relative proportions; all have the same form of stomach, not adapted for rumination; they have, with perhaps one exception, the same number and structure of teeth; that is, six incisors both above and below, one cuspidate on each side in both jaws, six molars above, and the same number below on each side, making forty teeth in all. The whole family is distinguished from all other mammalia, by the bones at the extremity of the feet being lodged in a single round hoof; they have all more or less mane on the neck; the whole of their structure is remarkably strong and well balanced, being in height at the shoulder and croup, about equal to the length from the breast to the buttock, and the head and neck comparatively lighter in proportion than in animals that bear horns; hence, above all other quadrupeds, the horse is the most symmetrical for his stature; the fleetest, the strongest, and the most enduring; for, considering that his speed is always reckoned with the additional weight of a rider, that velocity which gives near a mile in a minute, and four miles in six minutes and a half, has been calculated to be at the rate of eighty-two feet and a half, per second; exceeding what a vigorous stag, or the fleetest greyhound can achieve unencumbered by any extraneous weight. Such speed, with the powers of endurance, is surely superior to every other quadruped; for while we know what effect the difference of one or two pounds weight produces on the velocity of the pace of racers; horses will carry heavy riders, and keep up with a running ostrich, overtake a stag, and toil at a gallop in the withering sun of the desert, over sixty or eighty miles, without drawing bit. It is to the elasticity and form of structure, to the inclination of the shoulder, the width of the trunk giving play to the lungs, the breadth of the quarters, the vigor of the fore-arm, the consolidation of the foot into one hoof, and the lightness of the head and neck, that we must chiefly refer these powers.

Equidæ are essentially grazing animals; all are tempted by thistles, thorny shrubs, and brooms. They are gregarious, in common with ruminants they see well in the dark, have the pupil rather elongated, the eyes being placed far apart, so as to enable them, when the head is down, to view objects with facility before and behind them, as well as sideways; the length of head and neck is nearly equal to their height, giving the power of cropping the herbage, by means of their flexible lips, and well-set nipping teeth, to accomplish which they are nevertheless obliged to throw one of the fore-legs forward and the other to the rear, while at the same time they straighten the line of the 
back; the ears are very movable, independent of each other, conveying sound with facility from all directions; their sense of smell is very delicate; they sleep little; in a wild state seldom or never lie down, and consequently have an individual security as well as the collective protection of their gregarious habits ; most, however, prefer mountains and rocky regions, and with trifling exception all keep out of cover.

True horses resist the severest temperature, and can live in the coldest climates that will allow them to find food; and races or forms of them bear heat with nearly equal facility; but in the two extremes, somewhat of opposite effects take place; for while in the north, wild horses are not diminished in stature, the domestic become very small; and in the south, the domestic rise above the common standard, while the so called wild are not more than ten hands, at the shoulders.

There is a great disparity of intelligence, between all the wild species and the domestic horse, whose acts often display faculties nearly as elevated as those of a dog; memory almost as tenacious, and a power of abstraction and comparison, a degree of benevolence, and a generosity of disposition which, notwithstanding our common ruthless mode of educating them, often pierces through when least expected. Qualities of so elevated an order appear to be necessarily connected with greater irritability of nerve, and this sensitiveness is manifested in horses more than in other Equidæ, their skins suffering so much from the stings of flies, that Nature, in order to enable them to have leisure to feed and repose, has furnished their neck with a long mane, and the tail forms a sweeping brush which reaches every part of the body where the head cannot attain; they have moreover a quivering muscular action of the skin which impedes the tormenting power of insects.

The period of copulation, the time of gestation, the number of offspring, the years of growth, the conditions of dentition, and the duration of life, are in all nearly alike, or differ only from local causes; none appear to suffer convulsions from dentition; all are in disposition gay, sociable, and emulous; even the ass has the instinct of trying his speed against competitors; the voice of all is sonorous, loud, but, excepting in the horse, exceedingly disagreeable.

We divide the Linnæan genus Equus into three sections; the first contains the Horses properly so called; the second, the Asinine group; and the third, the South African striped species.

\section{THE HORSE.}

EQUUS CABALLUS.

In this section we place the true horses, wild and domesticated. They are distinguished by the mane being pendant and the tail furnished with long hair up to the root; the head is long, the ears short and pointed, the withers somewhat elevated, the shoulder oblique; they have callosities on the fore-arms and hind-canons; the hoof round; colors of the hair uniform, or clouded, or with a tendency to dappling; the voice consists in neighing; intellectual instinct naturally more developed than in the other species, though no doubt much perfected by long domestication. The wild will be described hereafter. 


\section{THE DOMESTIC HORSE.}

EQUUS CABALLUS DOMESTICUS.

In the domestic horse we behold an animal equally strong and beautiful; endowed with great docility and no less fire; with size and endurance joined to sobriety, speed and patience; clean, companionable, emulous, even generous ; forbearing, yet impetuous; with faculties susceptible of very considerable education, and perceptions which catch the spirit of man's intentions, lending his powers with the utmost readiness, and restraining them with as ready a compliance: saddled or in harness, laboring willingly, enjoying the sports of the field and exulting in the tumult of battle; used by mankind in the most laudable and necessary operations, and often the unconscious instrument of the most sanguinary passions; applauded, cherished, then neglected, and ultimately abandoned to the authority of the bipeds, who often show little superiority of reason and much less of temper. One who, like ourselves, has repeatedly owed life to the exertions of his horse, in meeting a hostile shock, in swimming across streams, and in passing on the edge of elevated precipices, will feel with us, when contemplating the qualities of this most valuable animal, emotions of gratitude and affection which others may not so readily appreciate.

A horse of the usual standard is now considered to attain the height of fifteen or fifteen hands and a half. In the east of Europe they range usually from below fourteen to fifteen hands. The gestation of mares lasts about eleven months, though sometimes the time is less by thirty-five days, and at others extended to forty-one or forty-two days beyond it; and foals are born usually in April and May. They see and have the use of their limbs shortly after birth; they are then short-bodied and short-necked animals, and very high on the legs; they are frolicsome and sport about the mother; scratching their own ears with the hind legs, and astonishing the stallion, if perchance he can approach, for the gambols of the colt set him on his mettle, his crest rises, his tail is flung up, he snorts and gallops in exceeding wonderment, and with marked signs of pleasure.

The foal at birth is usually already furnished with the first and second molars cut through the gum, and in little more than a week shows the two middle nippers or incisor teeth in both jaws, and after five weeks more the two next and also a third grinder : about the eighth month the third pair of incisors above and below are cut, and then the front of the mouth is full. The enamel on these teeth is hard and thick, forming forward a swelling above the edge which remains sharp, and within or behind the edge the surface is depressed and becomes dark, which constitutes the mark or evidence whereby the age of a colt or horse is determined. At the end of a year the fourth grinder appears above and below, and the fifth at the end of the second year, and then the first dentition is complete. When three years old, the central nippers in both jaws make room for a larger pair in each, and are the first of the permanent set; six months after, a second pair extrude the former on each side of the first permanent; and at four and a half the last set will be supplied, all distinctly bearing the mark; at five this mark begins to be effaced by the wearing of the two first pair, and the tushes or cuspidate teeth are exposed, leaving a space between the nippers, and approaching nearer to the grinders; at six years old the central nippers are without a mark, or nearly so ; at seven, in the next pair, it likewise disappears; and at eight, all the cutting teeth have lost their black stain and hollow. 
These are the marks for estimating the age of the horse till the animal is deemed old, and it may be proper to add, that there are further tokens taken from the tushes, \&c. The age of a horse is always calculated from the first of May, and there is considerable difference in the marks between stabled horses, crib-biters, and animals usually at grass.

A full grown horse, notwithstanding the different purposes he may be intended for, is required to possess some general qualifications in order to be valuable; the head should be middle sized, well set on, with the branches of the lower jaw sufficiently separated to give the head liberty of action; the eyes large and rather promiment; the ear small, erect, lively; the nostrils open, not fleshy; the neck long, with little curve along the gullet, but arched on the crest; full below, slender near the head; the withers somewhat high, and the shoulder slanting backwards, but more vertical in proportion if the animal is destined for draught; the chest should be capacious, deeper in horses for speed, rounder for others; the arm muscular, the canon bones forward, flat and short; the loins broad and the quarters long; the thigh muscular, the calcis high, and the whole hock well bent under the horse. It is in the structure of the bones of the hind quarters that the principal characteristics of high bred horses are detected, and the straight horizontal line of the croup gives those attached to the pelvis greater length, and consequently greater angles; whence the power of throwing the weight forward is chiefly derived.

From the different colors of the original stocks, horses are clothed in a greater diversity of liveries than any other animals, cattle and dogs not excepted; they are a natural consequence of interminable crossings of the five great stirpes, producing combinations which have caused French and Spanish writers to enumerate above sixty; the piebald and dappled find only their counterparts in the forms and shades of color in some species of Seals, and it is there, also, we find the light blue grays with brown spots, of which we have examples in the New Forest and in Spain; yet, excepting the five primitive, all the rest have a tendency to return to them, and sometimes it would seem capriciously to resume the bay, dun, gray or black.

The life of horses extends naturally from twenty-five to thirty years ; cases have occurred of individuals attaining the age of more than forty; and in countries where they are not tasked by constant over exertion, the period of existence is usually between nineteen and twenty-one. But in some countries the destruction of these noble animals is excessive; the value of time with a commercial people, incessantly urged into activity both mental and corporeal, has demanded rapidity of communication, and spread an universal taste for going fast; the fine roads have permitted horses to be subjected to more than they can draw; betting, racing and hunting are pursued by persons whose animals are not constructed for such exertions; and violent usage in grooms, stable-boys, and farm-servants is so common, that few reach the age of fifteen years, and all are truly old at ten.

In the structure of the horse, mares are always comparatively lower at the withers than geldings or stallions; these last have the neck much fuller than either of the above; their spirit is also much more noisy, and their disposition, when they meet at liberty, exceedingly pugnacious; they are commonly used for the saddle, as, for instance, in India, two horsemen cannot venture to ride side by side without constant attention, and always at some distance asunder.

It is asserted that horses with a broad after-head, and the ears far asunder, are naturally bolder than those whose head is narrow above the fore-lock; some are certainly 
more daring by nature than others, and judicious training in most cases makes them sufficiently stanch. Some, habituated to war, will drop their head, pick at grass in the midst of fire, smoke, and the roar of cannon; others never entirely cast off their natural timidity.

Horses have a very good memory; they remember kind treatment; in the darkest nights they will find their way homeward, if they have but once passed over the same road.

We all know to what extent horses may be educated to perform a variety of tricks, appear dead, simulate fear or rage, \&c., \&c.

In submission to a master, the horse is affected by kind treatment as much as the dog and elephant; for although habitually his actions show timidity, they are more an effect of good temper than fear, for where severity is unreasonably exercised, obedience readily granted to kind treatment becomes doubtful, and sooner or later breaks out in vicious resentment, and oppression has its limits.

In emulation to surpass a rival, no more convincing instance can be cited than in the case of a race-horse finding his competitor begin to head him in the course, seizing him by the fore-leg with such firm teeth, that both jockeys were obliged to dismount to part them.

All these intellectual and moral qualities vary in horses as much as the physical; for spirit and daring is not more universal than timidity and cowardice; memory, prudence, aptitude in some, heedlessness, stupidity, and obstinacy in others ; these distinctions are not always individual, but commonly generical, and propagated with the other character of races and breeds, enter in the composition of the original forms of each stock; and it will be found in treating of them, that the most beautiful and noble are also the most gentle and most educated.

\section{THE ARABIAN RACE.}

Habitually in company with mankind, all the Arabian breeds become exceedingly gentle and intelligent; a look or a gesture is sufficient to make them stop, take up with their teeth the rider's jereed, or any other object he may have dropped, stand by him if he has fallen off their backs, come to his call, and fight resolutely in his defence; even if he be sleeping they will rouse him in case of danger.

Although the Arabian steed may not be acknowledged by amateurs, of exceeding fast going, as perfect in form, no race is possessed of a more beautiful head, for above the eyes it is squarer, and below the nose is plane and more tapering than any other; the muzzle being fine, short, and adorned with wide and delicate nostrils; the eyes are very prominent, large, and brilliant; the ears small, pointed, movable; the jaws and cheeks adorned with minute swelling veins; the head is well set on the neck, which arches gracefully, and is bedecked with a fine but rather deficient mane; the withers are high; the shoulders inclining and beautifully adjusted; the chest and body perhaps not sufficiently ample, but yet spreading out behind the arms to give room for action to the lungs and heart, which are in proportion larger than in any other kind of horse; the limbs are remarkably fine, sinewy, and firmly jointed; the legs flat and clean, with pasterns rather long and flexible, so that with an oblique position they appear to the heavier European not quite so strong as is desirable; but considering that in stature these horses do not often exceed fourteen hands and three-quarters, it is evident from 
the length of time they will carry a rider at great speed, and under great restriction of food, and the number of years they endure, that for their climate at least they are fully competent to accomplish all that is desirable, and even execute tasks which are not always believed of them. The quarters of an Arab are deep, the muscles of the forearm and thigh prominent; the tail set on high, with a middling proportion of sweeping hair; the skin on all parts of the body thin, presenting veins above the surface; and the hoofs, rather high, are hard and tough.

From the broad forehead and space between the ears, judges assert their greater courage and intelligence, which, aided by education and kind treatment, they certainly possess beyond all other horses; and in sobriety, temper and docility, none can be compared to them.-See Plate, No. 1, Marengo Arabe, once the property of the Emperor Napoleon; white breed of the bay stock.

\section{THE SHRUBAT-UR-REECH, OR DRINKER OF THE WIND.}

On the sandy plains, south of Atlas; are the Drinkers of the Wind, reared by the Mograbins of the West; they are brown or gray, rather low, shaped like greyhounds, destitute of flesh, or, as M. Davidson terms it, like a bag of bones; but their spirit is high, and endurance of fatigue prodigious.-See Plate, No. 2.

\section{THE ENGLISH RACE-HORSE.}

In shape, the race-horse, if we except his superior stature, is very like the noblest Arab, with similar eyes, ears, and head gracefully set on the neck; long oblique shoulders, high withers, powerful quarters, hocks well placed under their weight, vigorous arms and flat legs, short from the knee to the pasterns, these long and elastic; the tail placed high, not superabundantly furnished with long hair, and the mane likewise rather thin and drooping; the colors of the blood-horse are bay, chestnut, brown, black, and gray, but never dun, Isabella, or roan; the black itself being a residue of ancient foreign alloy, derived either from the old English, the Spanish, or Barbary breeds. Such is the blood-horse racer.-See Plate, No. 3, the English race-horse Eclipse.

\section{THE SCOTTISH, OR SHETLAND PONY.}

Some of which scarcely exceed in size the stature of a large dog, and have been actually carried in a gig. Yet there are among them many handsome shaggy little animals, with huge manes and abundance of tail; they are of all colors, but it is not difficult to perceive the original dun stock as forming the parent race.-See Plate, No. 4.

\section{THE TANGUM-PIEBALD PRIMEVAL STOCK OF TIBET.}

This form of the domesticated horse appears to claim a distinct specific existence, inasmuch as the typical animal is found with its characteristic marks in a state perfectly wild, and it appears unmixed with wild horses of other shape or colors.-See Plate, No. 5 .

\section{CRISP-HAIRED HORSE-PRIMEVAL BLACK STOCK.}

The Black Stock, reproducing everywhere in Europe horses of a large stature, extends, with little intermixture, down the Danube and through Central Germany, Silesia, Moravia, and Bohemia, to the north side of the Balkan in Turkey.

See Plate, No. 6. 


\section{THE NATURALIST.}

\section{ORNITHOLOGY.}

\section{NATURAL HISTORY OF HUMMING-BIRDS.}

These beautiful and delicate beings appear to have excited the admiration of their discoverers, and, indeed, of every one who has observed them, either reveling in their native glades, or at rest in the more artificial display of our museums, by the spirited proportions of their form, and the dazzling splendor of their plumage,

"Delicate and beautiful,

Thick without burden, close as fishes' scales."

The ancient Mexicans used their feathers for superb mantles, in the time of Montezuma; and the pictures, so much extolled by Cortes, were embroidered with their skins; the Indian could appreciate their loveliness, delighting to adorn his bride with gems and jewelry, plucked from the starry frontlets of these beauteous forms. Every epithet which the ingenuity of language could invent, has been employed to depict the richness of their coloring; the lustres of the topaz, of emeralds and rubies, have been compared with them and applied in their names.

These birds are nearly confined to the tropical portions of the New World, and that great Archipelago of Islands, between Florida and the mouths of the Orinoco, with the main land of the Southern Continent, until it passes the Tropic of Capricorn, literally swarms with them. In the wild and uncultivated parts, they inhabit those forests of magnificent timber, overhung with lianas, and the superb tribe of Bignonaceæ, the huge trunks clothed with a rich drapery of parasites, whose blossoms only give way in beauty to the sparkling tints of their airy tenants ; but since the cultivation of various parts of the country, they abound in the gardens, and seem to delight in society; becoming familiar, and destitute of fear, hovering over one side of a shrub, while the fruit or flower is plucked from that opposite.

As we recede from the tropics, on either side, the numbers decrease, though some species are found in Mexico, and others in Peru, which do not appear to exist elsewhere. Mr. Bullock discovered several species at a high elevation, and consequently low temperature, on the lofty table lands of Mexico, and in the woods in the vicinity of the snowy mountains of Orizabo; while numerous members of this diminutive family, flung about in a snow storm, riear the Straits of Magellan.

Two species, only, extend far into the northern continent of America. The ruffnecked humming bird, discovered by Captain Cook in Nootka Sound; and the Northern humming-bird, so beautifully described by Wilson, has been obtained from the plains of the 
Saskachawan, and was found breeding near the sources of the Elk River; it is known to reach as far north as the 57 th parallel.

The humming-birds are of a lively and active disposition, almost constantly on the wing, and performing all their motions with great rapidity ; their flight is in darts, and it is at this time, in a brilliant sun, that the variations of their plumage are displayed with the greatest advantage.

"Each rapid movement gives a different dye ;

Like scales of burnished gold, they dazzling show,

Now sink to shade-now like a furnace glow."

But when performing a lengthened flight, as during migration, they pass through the air in long undulations, raising themselves for some distance, and then falling in a curve. When about to feed, or in search of a favorite flower, they hover stationary, surveying all around, and suddenly dart off to the object. They remain suspended in the air in a space barely sufficient for them to move their wings, and the humming noise proceeds entirely from the surprising velocity with which they perform that motion, by which they will keep their bodies in the air, apparently motionless, for hours together.

They seldom alight upon the ground, but perch easily on branches; they are also possessed of boldness and familiarity, and even attack and tease the king-bird. Among themselves they are exceedingly pugnacious, two males seldom meeting on the same bush or flower without a battle. In the gardens they flutter about without heeding intruders.

During the breeding season, if the nest is approached, they dart round with a humming sound, often passing within a few inches of the person; and should the young be newly hatched, the female will almost immediately resume her seat, though the intruders continue within a few yards distance. The intrepidity and jealousy of a diminutive Mexican species far exceeds the quiet courage of the Northern birds. When attending their young, they attack any bird indiscriminately that approaches the nest. Their motions, when under the influence of anger and fear, are very violent, and their flights rapid as an arrow. The eye cannot follow them, but the shrill piercing shriek which they utter on the wing, may be heard when the bird is invisible, and often lead to their destruction by preparing for their approach. They attack the eyes of the larger birds, and their sharp needle-like bill is a truly formidable weapon in that kind of warfare. Nothing can exceed their fierceness when one of their own species invades their territory during the breeding season; under the influence of jealousy they become perfect furies; their throats swell; their crests, tails and wings expand; they fight in the air, uttering a shrill noise, till one falls exhausted to the ground. When they see a man climb the tree where they have their nests, they fly at his face and strike him in the eyes, coming, going, and returning, with such swiftness that no man would rightly believe it that had not seen it.

The nests are built with great delicacy, but at the same time with much compactness and warmth. On the plains, near the Elk River, the nest of this hardy bird is built of the materials that are most appropriate in the country; the downy seeds of an anemone, bound with a few stalks of moss and lichen.

The nest of Trochilus Pella is principally composed of a spongy cellular substance, apparently similar to that of a fungus, of which some species of wasps build large habitations, suspended from the branches of trees in the virgin forests of Guiana.

The nest of the black humming-bird is also made of cotton, entwined round the thorns and twigs of the citron-tree, and is of so firm a texture as not to be easily broken 
by the winds. And the nest of the topaz-crested humming-bird, about seven-eighths of an inch in diameter, is composed of the same materials, stuck over with lichens on the outside, and firmly fixed in the hanging cleft of some strong creeper by threads of a cottony substance, and very slender roots or tendrils, the whole lower part as if cemented by a thin coat of glue.

Most writers agree in the fact, that humming-birds lay only two eggs, but the trochilus hirsutus lays only one. This small fecundity, with the many casualties which are liable to destroy them, the vicissitudes of season, and the assaults of various animals, birds, and even insects, will give us some idea in what immense profusion these little birds exist, when two, or at most four, is the number of young reared in a season.

The eggs are not so small in proportion as one would imagine on looking at the bird. That of the topaz-crested humming-bird is nearly five-eighths of an inch in length, and about three-eighths in diameter. In shape they are nearly a complete oval, and of a pure and delicate white. The period of incubation is remarkably short; the black humming-bird sits twelve days, and the young leave the nest and follow their parents in eighteen days; and the North American species, according to Audubon, hatches only ten days, and the young are ready to fly in one week.

The desire to possess creatures of such beauty in a tame state, has induced persons often to try the experiment of keeping them in cages, though yet comparatively without success.

When we examine attentively the structure of any bird, we soon come to the conclusion that the most important parts of its outward form are those organs which serve for the means of transporting it from place to place. On presenting a humming-bird to the most common observer, the first exclamation generally is, "What a beautiful little creature!" The second, "But what large wings it has!" Such, indeed, is the case, and in most instances the size of the wings and strength of their quills are entirely out of proportion to our ideas of symmetry in a creature clothed with feathers; but, upon comparing them with its necessities, and the other parts of its frame, their utility and design become obvious. All their other parts, not called into action during flight, are very slender, almost frail; their tarsi are short, and the feet small, so as not to incommode during flight, while they point out an inability for any long support or assistance in procuring sustenance, by climbing or hanging in various positions, as we see employed by the titmice, and many of the slender-billed warblers. Their food is derived from the sweet nectar of flowers, or from insects which must either be taken in a rapid flight, or withdrawn from the deep tube, or cup-shaped recess of blossoms which grow and hang in every direction, and which it would be impossible to reach unless by suspension above or under. Another great necessity for their possessing organs of such power, is to enable them to pass in safety through the migrations, and the long flights which are sometimes necessary for their preservation, and during which they have often to withstand a passing gale, showers, or even the rigor of a snow-storm. The beautiful climes where we have seen they inhabit, are at seasons subject to perpetual rains, which drench and almost inundate their abodes, or to hurricanes that in a few minutes leave only a wreck of all that was before so magnificent and luxuriant; and they pass by these means before the dangerous season, to districts where the reparation of a previous wreck is proceeding with all the magical rapidity of tropical vegetation.

The wings in general exceed the tail in length, unless when that member is extra. 
ordinarily developed. The exterior outline of the wing is very much curved, and the first quill is always longest, the others shortening gradually. The secondaries are very short, and the lesser wing-coverts occupy little space. The plumulets of the quills are narrow and compact, firmly united together, forming a substance, when used, almost like a thin plate of whalebone, and which, by presenting resistance to the air when struck, and allowing no part to pass through the webs, as in nocturnal feeding birds, produces the humming sound which is heard during their suspension, and whence their common name has been applied.

The organ of next importance, as directing the flight, is the tail. This is always powerful, and presents every modification which we find in those birds endowed with powerful or rapid flight.

The bill is always an important organ in birds. This family presents great modification of form, which will be seen by inspecting the plates, and will be further illustrated when we characterize the divisions.

The tongue is very long, retractile, and capable of being darted out with considerable force. It is composed of two muscular tubes joined together for the greater part of their length; and terminated in a spoonlike point on the upper surface. They assist in retaining the different substances, which are immediately conveyed to the opening of the csophagus by the contractility of the tubes.

Their feet are very small and slender. The claws are rather large in proportion, very much hooked, very sharp, and may thereby assist in securing a firmer grasp.

\section{TROCHILUS ORNATUS.}

THE TUFT-NECKED HUMMING-BIRD.

Among the curious forms assumed by the plumage of the humming-birds, we have seen various feathered excrescences issuing from different parts of the body, and in none are they so singular as in the tribe which our present species represent. They are called, by the French, coquets.

In this bird, in addition to an ample crest of clear reddish chestnut upon the head, the sides of the neck are adorned with tufts of narrow feathers, almost an inch in length; they are composed of from ten to twenty plumes, of the same color with the crest, and are terminated with a broadened tip of clear shining green. The throat and upper part of the breast, with the forehead, bordering the rufous crest, is covered with bright emerald-green scaly feathers, which are separated from the upper parts by a line of a paler shade running through the eyes to the rictus, and from the lower part of the breast and belly, by a band of rufous of the same tint with the crest; the upper parts are of a bronzed green, with steel-blue reflections; and this is again separated from the tail by a conspicuous band of grayish white. The tail is broad and ample ; the centre feathers greenish; the others deep chestnut red, with purplish reflections.-See Plate, No. 1.

\section{TROCHILUS CORA.}

THE CORA HUMMING-BIRD.

The whole length of this little bird is about five inches five lines, of which the tail makes three inches and two lines. The upper part of the head, back, rump, and 
wing-coverts, are of a uniform brilliant green; the feathers of the throat, neck and cheeks, are of a bluish or steely lustre, and have the form of scales; the remaining lower parts of the body are of a dingy white, brownish on the flanks; the tail feathers are white at the base of the inner webs, brownish on the outer, and towards the tips the feet are reddish.-See Plate, No. 2.

\section{TROCHILUS COLUBRIS.}

\section{NORTHERN HUMMING-BIRD.}

Our present species is one of the most hardy, and bears a range of temperature almost from tropical heat to the rigor of an arctic latitude, having been lately observed as far North as the plains of the Saskachawan and the banks of the Elk River. It is only during summer that an excursion of such distance is made, and we find their arrival, during migration, occurring at different periods, in various parts of the Canadas and the United States.

About the 25th of April, the humming bird usually arrives in Pennsylvania, and about the 10th of May begins to build its nest. In the Savanna in Georgia, it appears from the South about the 23d of March, two weeks earlier than it does sixty miles higher up the country.

The Northern Humming Bird is three inches and a-half in length, and four and a-quarter in extent; the whole back, upper part of the neck, sides, under the wings, tail-coverts, and two middle feathers of the tail, are of a rich golden green; the tail and wings are deep brownish purple; the sides of the belly, and belly itself, dusky white, mixed with green. But what constitutes the chief ornament of this little bird, is the splendor of the feathers of his throat, which, when placed in a proper position, glow with all the brilliancy of the ruby; these feathers are of singular strength and texture, lying close together like scales, and vary, when moved before the eye, from a deep black to a fiery crimson and a burning orange.-See Plate, No. 3.

\section{TROCHILUS PRASINA.}

\section{GOLDEN-GREEN HUMMING-BIRD.}

The entire length of this beautiful little bird is about two inches and eight lines, of which the bill makes up seven lines, and the form is in general delicate, the whole plumage, excepting the vent, is of a very deep golden-green, but with a clear, brilliant, and changing lustre, occasionally of a bluish tint; the plumes on the forehead and breast, presenting the greatest brightness, and assuming the scaly form, the vent is whitish; the wings are brownish purple, of a narrow form, and firm texture; the tail, dull indigo blue, broad and slightly rounded.-See Plate, No. 4.

\section{TROCHILUS DELALANDII.}

DELALANDE'S HUMMING-BIRD.

The crown of this bird is adorned with a beautiful crest, composed of short feathers, with generally one narrow and elongated, which rises in the centre, to an inch in length; it is of a rich and deep blue, tipped with white, and appears very graceful, either when erected, or reclining, and folded at rest, behind the eye ; upon the auric- 
ulars there is a small, nearly circular patch of clear white, which forms a conspicuous object; the fore-part of the throat, breast, and belly, are rich azure blue, surrounded with gray; the head, back, flanks, and wing coverts, bright and shining green; the vent and flanks are gray; the wings are brownish purple; the centre feathers of the tail of the color of the upper parts; the remaining feathers are dull blue, and the outer feathers have a conspicuous spot of clear white at the extremities.

See Plate, No. 5.

\section{TROCHILUS CORNUTUS.}

DOUBLE-CRESTED HUMMING-BIRD.

This hunming-bird is about four inches in length, of which the tail alone measures nearly the half; the bill and feet are remarkably slender, the former slightly bent, terminating in a very fine point. The most characteristic mark of this species is the two flattened crests, composed of six feathers, which divide in front of the head, on a level with the eyes, and are directed forwards.

The colors of these tufts certainly baffle description, and an idea can only be conveyed by likening them to some familiar object, such as the bright and changing hues of steel, and other metals, or the sparkling tints of precious stones; the entire of the forehead between the tufts is covered with scaly feathers, of brilliant green and blue reflections. A gorget of deep and rich purple, composed of lengthened feathers, reaches from behind the eyes, upon the breast ; the breast and upper parts of the belly are of the purest white; the same color crosses the lower sides of the neck, nearly meeting on the back, and forms a beautiful contrast to the deep colored and delicately formed feathers of the gorget; the belly and vent are of the same green with the upper parts; the wings are brown; the tail is strongly wedge-shaped; the two centre feathers brown; the others pure white.-See Plate, No. 6.

\section{TROCHILUS MAGNIFICUS.}

MAGNIFICENT HUMMING-BIRD.

The adult male has the neck adorned with beautiful plumulets of snowy white, relieved by a black or very dark olive-green band on the tip of each. These tufts are also far different, the feathers are much shorter and broader, and scarcely present so stiff an appearance, as those of its congeners, while the ruff extends nearly round like a gorget in front. In the young males neither the crest nor ruff appears; the crown of the head is of a dull yellowish red, changing into a darker and grayer shade towards the hind head, which runs in a line from the eye to the shoulders; the upper parts are of a rich green, and are separated by the above mentioned line from the lower region of the body, which is of a grayish white, tinged with rufous on the throat and breast, and entirely devoid of the brilliant scaly plumes occupying the throat of the adult. It is a native of Brazil.

See Plate, No. 7. 


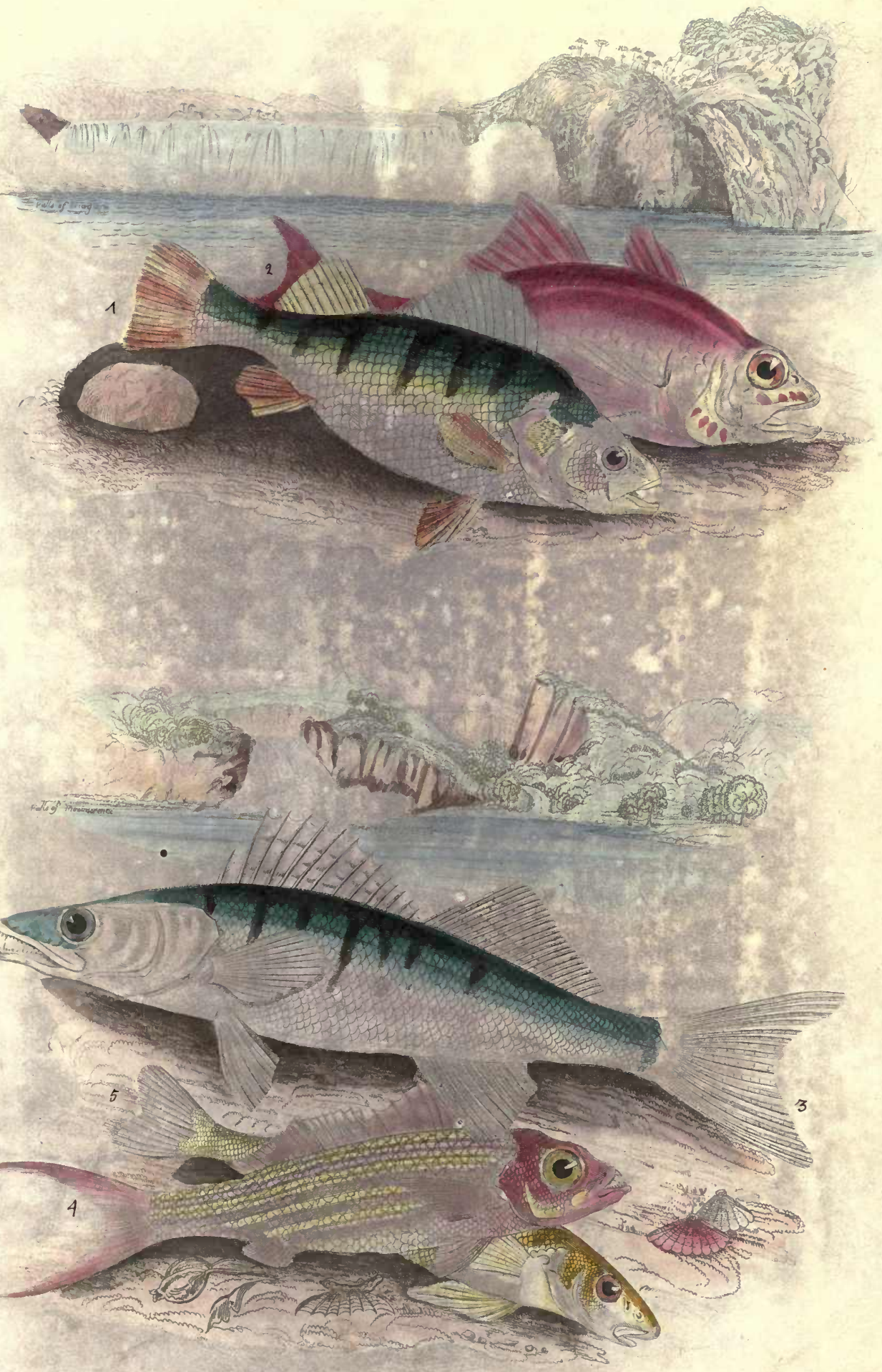


4 


\section{THE NATURALIST.}

\section{YCHTHYOLOGY.}

\section{THE NATURAL HISTORY OF FISHES.}

THE study of fishes, technically termed Ychthyology, was, perhaps, longer in being brought to what might be called a science, than the histories and descriptions of animals and birds. The difficulty of procuring a numerous series of individuals, and the impossibility of penetrating and pursuing them in the deep recesses of the ocean, withdrew the constant charm which novelty of form threw over the branches constituted by those animals which inhabited the same element with ourselves.

Living in a different element from that which maintains most of the mammalia and birds, we find the external covering of fishes to consist of plates, or scales, supplying the place of hair or feathers. The skin of fishes completely surrounds the body, clasping close to the muscles, and serving as an outward skeleton, as the bones do for a protection to the inward parts. The scales are composed of two substances, the one allied to that of horn, the other to that which forms the enamel of teeth.

The scales are held in position by a fold of the epidermis, often so delicate as scarcely to be visible; but which covers almost the whole part of the fish exposed to our view. They fold over each other in different modes of imbrication; sometimes regularly, like the tiling of a house; sometimes in a lateral form, or with the lower longitudinal edge folding over the upper edge of the scale below; sometimes alternately, so that the joining of the preceding scale is opposite the centre of that which follows, while in others there is no imbrication at all, and the edges meet like plates, or the flags of a pavement.

The Baron Cuvier assumes the common perch among fishes as the form in which the greatest general perfection is exhibited, (see plate No. 1,) and being a species familiarly known to every one, will serve to convey an idea of this class of beings.

In the perch, and indeed in all those fishes which are endowed with extensive locomotive powers, or require swiftness to seize their prey, the tail is the great organ of motion, while the fins are the balancers or directors, a contrary arrangement to that shown in the members of those creatures of the land and air, where the tail is the director or helm, the feet and wings the movers. The fins on the upper surface serve to balance the body, those of the lower surface to turn it, to move it slowly, and to keep it suspended in strong currents; but in all these, the motion or assistance of the tail is observable. In very swift motion the fins are quiet; the creature could not keep them extended, far less use them, and they fold closely to the body, and offer no resistance to its rapid passage through the water.

The senses among fishes may almost be said to be confined to three-those of seeing; 
hearing, and smelling, all very acute. Those of taste and touch are to all appearance in subordinate development, nor with the powerful exercise of the others are they conducive, or necessary to the existence of the individual. There is a general sense of feeling by contact with any body over the surface of the animal; but unless in those species which are furnished with long filamentous appendages to the head, there is no organ by which this property is regularly exercised. In those fish, when lying at the bottom in disturbed water, the filaments are extended, and may serve to make them aware of the approach of an enemy; and among others, (in the Siluri,) where they are of great length, and are thrown out and moved, to attract attention; from their sensibility of touch, while the fish remains in concealment, they may warn the lurker that his prey approaches, and enable him to prepare for its seizure.

The sense of taste seems even developed in a less degree, the organ in which it is generally implanted being used as an accessory to prehension, and often armed with very strong teeth. Swallowing, also, almost immediately follows the seizure; the prey, gorged entire, and without mastication in the mouth, is rapidly dissolved and digested in the stomach.

The important function of vision is imparted to fishes to a greater extent, and if, perhaps, the range of seeing be not great, when within its bounds it is apparently acute and distinct; and as among the higher vertebrata we have some which are nocturnal in their habits, as well as those which seek their prey by day, so we find among fishes a difference of form in the large eyes of many species which constantly remain at a depth of many hundred fathoms below the surface, and where it has been proved that the influence of light could not extend. In some, again, the eyes are remarkable for their minuteness, and to several species the specific name Caca, or blind, has been applied. These, like the mole in her dark galleries, live in the banks of muddy rivers, and are no doubt furnished with some more exquisite sense to supply their wants, and minister to their sustenance. In the Gastrobranchus, a fish remarkable in all its structure, no trace whatever of eyes has yet been discovered.

Water, the medium through which fishes hear, has been proved to be a better conductor of sound than air; and, from a variety of experiments, sounds produced under water have a loud and clear impression on the human ear, placed in the same situation. In fishes there is no external ear, except in a few where a very small cavity is discernible. They want the tympanum, the small bones, and the eustachian tubes; but the semi-circular canals are often largely developed. In the osseous fishes, the whole of the labyrinth of the ear projects into the cavity of the cranium. The labyrinth is filled with a transparent liquid, distending the vestibule and sack, which contain small and peculiar bony substances, two or three in number, which float in the liquid, and would apparently convey the sense of any concussion to the nervous linings of the edges, and upon the principal plexus of the auditory nerve, which is ramified in the greatest proportion on the walls of the sack, which generally contains the largest of these hard osseous bodies.

The structure of the ears in fishes is certainly less perfect and less complicated than in the higher mammalia and birds; and Cuvier is of opinion, that though they hear sounds distinctly, or as concussions, yet they are unable to distinguish any of the finer tones or variations. That they are sensible of the impulses of sound has often been proved, and fish are known to approach for food at the whistle of their keeper. The Romans were even said to have taught each to approach upon being called by a particular name. 
Smelling, again, appears to be even farther developed than what is generally supposed. The nostrils, in general, appear externally like a double hole or opening, and the branches of the nerve are ramified on a sort of cushion at the bottom or upon the side. In a few, they are like prolonged tubes, as among the eels, where the multiplicity of nervous filaments is very great; and in one fish they are remarkable as being placed on a sort of stalk like a mushroom, in which the openings are placed with the nervous distribution. Seeing, then, a certain extent of development, we cannot doubt that impressions of smell are conveyed. In proof, various perfumes are successfully used by anglers to attract the fishes.

But Cuvier hints at this sense being even of service for a purpose of more delicacythat of distinguishing the difference between waters of different streams or currents; and it is probable, that, by the use of these organs, many of our migratory fresh water species are enabled again to discover and return to the rivers they had previously frequented.

Such seems to be the most common distribution of the three most prevalent senses. Various, however, are the modifications of their application, corresponding with the manners and necessities of the individuals.

The greater proportion of fishes are carnivorous, and find an abundant and varied food in the immense profusion of moluscous animals, as well as in the smaller species of their own orders, for among them may be said to exist a constant system of attack and defence-a general war, the stronger against the weaker. A few only subsist on vegebles, and graze the sea-weed, their pasture. The teeth, the only organs almost of prehension, are therefore varied in innumerable forms, but are chiefly adapted either for tearing or bruising. In the cartilaginous fish, we find these forms strongly developed; those of the sharks will exhibit an example of the first, of the most formidable kind, of great size and strength, smooth and piercing, or sharp, but serrated. Those of the rays or skates of the second, fitted for bruising, where the food is in a great part shell-fish, and where the teeth are arranged as a dense pavement. In others, again, the teeth, various in size and strength, are placed in the jaws, vomer, tongue, arches of the bronchiæ, and in the throat. The latter arrangement is one of the most singular, and bears the title among French ychthyologists of "dents en velour," from their exhibiting the appearance, to the naked eye, of the pile of coarse velvet. These act by the compression of the lower pharyngeal muscles, and an example will be found in the genus Cyprinus, to which belong the greater part of those fishes which, by English anglers, are denominated "leather mouths." The food being seized, is almost immediately swallowed; and such is its voracity, that substances entirely foreign are often taken in, as may almost always be seen on examining the stomach of a cod, which sometimes presents a most heterogeneous mass, little fitted for nutrition.

Although the teeth and jaws, with pursuit, are the principal accessaries for securing prey, various fishes, deprived of swiftness, entice their prey by stratagem. Such are all the Siluri, with long filamentous appendages to the lips, which, in some, are said to possess the property of stinging. Others, again, lurk in concealment, and dart out upon the casual passers by. The Rostrated Chætodon employs a most singular property of propelling a drop of water with unerring aim and considerable force at insects which have settled on aquatic plants, seizing them on their fall into the water. But of all the properties with which these singular creatures are endowed, either for attack or defence, that of the benumbing and electric stroke of the Torpedo and Gymnotus is the most remarkable. Experiments have tended to confirm its connection with the galvanic 
influence. Many an assailant must be most unexpectedly stopped by it; and the fishes which are endowed with it being, in general, of slow motion, lurk until their victims approach within the influence of their deadly and peculiar power.

The reproduction and migration of fish is another part of their history full of interest. They are, with a few exceptions, oviparous, and fruitful to a most surprising degreeso much so, that if the whole ova were to be matured, bounds could not be assigned to them, and the expanse of the waters would be crammed; but among the millions of ova which are deposited, those hatched to maturity will not exceed one in the thousand, perhaps a much less proportion, and in their great fertility we see both a beneficent design in furnishing an ample supply of food for many of the inhabitants of the same element, and for the numerous tribes of waterfowl which, at some seasons, feed entirely on the eggs and fry; while, on the other hand, without this abundant power of generation, a stock could not be saved from the numerous enemies of sea and air to which they are nearly cxnstantly exposed. In general, the eggs are deposited in water comparatively shallow, upon rocks, or gravelly or sandy banks, on aquatic plants, or marine algæ, or in holes formed in the banks or borders of the lakes or rivers; and to the strong instinctive principle which impels these creatures to seek suitable situations for the deposition of their spawn, do we owe the abundant supply of fish which annually resort to our shore.

There is one circumstance in the breeding of fishes which requires notice-that of no care being bestowed on the ova, or young, after a place has been selected and finished for the deposition, or after they are hatched. There seem, however, here also, to be exceptions. The Caltichthys littoralis makes a regular nest of long leaves, or grass, in which they lay their eggs in a flattened cluster, and cover them over most carefully. They remain by the side of the nest till the spawn is hatched, with as much solicitude as a hen guards her eggs, both male and female, for they are monogamous, steadily watching the spawn, and courageously attacking any assailant.

In their economical uses to man, fish are principally important as an article of food, and from the employment they afford to the more dependent classes ; but oil is the commodity greatest in value and quality, produced from them. The quantity of fish killed for these purposes, is truly immense. What then will be the aggregate of the creatures in this department of zoology which are yearly consumed in our commerce? Isinglass is made from the swimming bladders; glue from the coarser refuse of fins; artificial pearls from the scales, \&c.

\section{GENUS PERCA.}

\section{PERCH.}

The genus Perca, first and typical of the family, is familiarly known in the form of the Common Perch. The characters may be shortly stated:-Preopercle, toothed; opercle, spined; suborbitary bones, delicately toothed; tongue free. The dorsal fins are very powerful, the spines strong and sharp. The scaling moderately large, and with the posterior edge toothed. Swimming bladder very large. Number of vertebræ in the common species, forty-two. They are all inhabitants of the fresh waters, delighting in lakes and still running streams. Feed on marine insects and small fish. The colors are 
often brilliant, disposed in bands on the body, or distributed in vivid tints on the fins, which contrast with the more sombre shades. They inhabit North America, Europe, India, the sea-like lakes of America, and the sluggish parts of her vast rivers afford the most numerous species.

\section{PERCA GRANULATA.}

THE GRANULATED PERCH.

No. 1. The Granulated Perch inhabits the rivers which flow from the Blue Mountains, towards the Atlantic Ocean, and, with two others from the same country, is so similar to that of Europe, as to have been confounded with it, and to have assisted in the idea that the latter was also found in the New World.

In the shape of the Perch, we find that combination of length, depth, and thickness, which will give the easiest support in, and the least resistance when passing through the water; while the fin possesses great power, the swimming or air-bladder is of great size, and the scaling or outward covering is compact, hard, and not awkwardly large. In coloring it is extremely beautiful, the upper parts of a rich olive green, shading into golden yellow; the body banded with distinct bars, of a deeper tint; and the whole relieved by the deep velvety black of the posterior part of the dorsal fin, and the brilliant vermilion of the central and anal fins. For defence, the strong spines of the dorsal fin, which are erected and held fixed with extraordinary muscular power upon the appearance of any danger, are admirably fitted, and it is one of the few fishes which is able to frequent waters in common with the Pike.

The common Perch still continues the species which is most accurately known, and, among the fishes which are used in the economy of man, was one of those which were perhaps most extensively and anciently used. It was known to the Greeks and Romans, and was celebrated for its beauty and delicacy, in the latter quality being thought worthy of contesting the palm with the far-famed Mullet.

As an article of food or luxury, we cannot agree with its cellebrator, Ausonius, in its excellency over our other fresh water fishes. When of average size, it affords a fine variety for the table, but will be surpassed in delicacy by either the Trout or Salmon.

The skins are used by the Laplanders, cooked into a kind of jelly, and for making glue; and celebrated dishes are prepared from their melts; while of their scales, whitened and cleaned, many pretty ornaments have been lately made.

\section{LABRAX LUPUS.}

THE BASS, OR SEA-PERCH.

No. 2. This fish was well known to the ancients; it was celebrated as well for the excellency of its flavor, as for the stratagems it used when encircled by nets, or fastened by the hook. Its general length is from ten to eighteen and twenty inches, though it is said to grow much larger; and being a bold fish, and active in its habits, it thus obtained its name of Lupus, or Wolf. 


\section{LUCIOPERCA SANDRA.}

THE COMMON PIKE-PERCH.

No. 3. It is a fish of rapid growth, and attains a length of three to four feet, and a weight of twenty pounds. Its flesh is of an agreeable taste, rich, and when cooked remarkably white.

The general colors of this fish, though less gaudy than those of the perch, are chaste and simple; the back and upper parts are of a greenish gray, changing, on the sides and belly, to silvery white.

\section{ETELIS CARBUNCULUS.}

THE RUBY-COLORED ETELIS.

No. 4. This genus is formed from a single specimen, and from the beauty of its coloring, which Cuvier compares with the tints of the ruby, has received the specific name of Carbunculus. It differs from the Perches in possessing strong and long teeth.

The eye of this splendid fish is a conspicuous object, and is of a golden orange; the scaling is large and marked; and the whole ground color of the fish is bright ruby red, relieved by stripes of golden yellow, which run along the ridges of the scales; its length is about eleven inches.

\section{ASPRO VULGARIS.}

THE ZINGEL.

No. 5. The little fish forming this genus, is at once distinguished by the lengthened form of the body, and by the situation of the mouth, which is almost placed under the snout or nose, that part being rounded and projecting over it; it is also remarkable for the roughness of its scales, whence by Rondoletius it was said to receive its name Asperus.

It seldom exceeds six or seven inches in length, but is used at table, and is esteemed good and delicate. By the fishermen of the Rhone, it is termed "Sorcier."

Three varieties are distinguished, of a black, gray, and yellow color. 


\section{THE NATURALIST.}

\section{ENTOMOLOGY.}

\section{LEPIDOPTERA.}

NATURAL HISTORY OF BUTTERFLIES.

The primary division, or order, of the class of insects, acquires its name, like all the other Linnean orders, from the characters presented by the wings. These members have their entire surface covered with a thick coating of minute imbricated scales, which has caused the insects to be designated by the name Lepidoptera. This clothing, however, is not universal in the group, as there are several genera partially denuded of scales, and others in which the wings are clear and transparent, without any traces of them. But these occasional deviations from the prevailing structure indicate no essential disagreement, nor do they disturb the regularity of the order, which is perhaps the most natural and best defined of the whole.

The species which it includes are popularly known as Butterflies, Hawk-moths, and Moths; terms which nearly correspond to the genera Papilio, Sphinx, and Phalæna, founded on the seasons of flight, Diurnal, Crepuscular, and Nocturnal. Many of these are among our most common insects; and the curious economy of some, and the remarkable beauty of others, have long attracted the notice of observers; while their varied forms and gorgeous coloring have afforded subjects of the highest interest to the lovers of the pictorial art. Their amount is so considerable, that the Lepidepterous order ranks among the most extensive with which we are acquainted. There is reason to believe, that it is surpassed only by the Coleoptera or Beetles.

The Diurnal Lepidoptera, or such as fly during the day, are the kinds known by the name Butterfly. This term is a literal translation of the Saxon word Butter-fleoza, and is supposed to be applied because the insects first become prevalent in the beginning of the season for butter. They are distinguished from the other scaly-winged kinds, by possessing antennæ with a knob or club at the summit, and holding their wings, when in a state of repose, erect or very slightly inclined.

Their wings are augmented to a size that seems quite disproportionate to that of the body, as if nature had wished to enlarge the surface on which she was to employ her pencil, that it might admit of more varied and profuse decoration. Even the under face of the wings, contrary to what is observed in other flying animals, is usually as much adorned as the surface, and often in an entirely different manner. Each wing, therefore, presents what may be called two different pictures.

The habits of these insects are well fitted to confirm the preference we assign to their beauty. Butterflies derive their sustenance from the nectareous juices and secretion of 
fruits and flowers; they are generally seen either sporting in the air, or resting on the disk of some expanded flower, and all their habits are such as beseem "pure creatures of the element." They are seldom noticed but in fine weather, and never in profusion but when the season is in its highest bloom, and their appearance then becomes associated in our minds with the charms of external nature, and is connected with those images of life and beauty which give rise to many of the genial influences of summer. Several species also contrive to outlive the winter, although their frail forms seem but ill adapted to resist the rigors of that inclement season, and issuing from their retreats in the first warm days of spring, are among the earliest and not least interesting heralds of the purple year.

The diurnal Lepidoptera are very numerous in species; they abound in all tropical countries, but a great proportion of the largest and most highly ornamented kinds are natives of America, especially of Brazil.

The mode of painting employed to produce these rich tints, may not improperly be called a kind of natural mosaic, for the colors invariably reside in the scales, which form a dense covering over the whole surface. These scales are usually of an oval or elongated form, and truncated at the tip, where they are occasionally divided into teeth; but sometimes they are conical, linear, or triangular. They are fixed in the wing by means of a narrow pedicle, and are most commonly disposed in transverse rows, placed close together, and overlapping each other like the tiles of a roof. In some instances, they are placed without any regular order, and in certain cases they appear to be two layers of scales on both sides of the wings. When they are rubbed off, the wing is found to consist of an elastic membrane, thin and transparent, and marked with slightly indented lines, forming a kind of groove for the insertion of the scales. The latter are so minute that they appear to the naked eye like powder or dust, and as they are very closely placed, their numbers on a single insect are astonishingly great. Leeuwenhoek counted upwards of 400,000 on the wing of the silk moth.

Both the different kinds of eyes which occur among insects, are to be found in the diurnal Lepidoptera. The ordinary, or compound eyes, are large and hemispherical, occupying the greater part of the head, and no fewer then 17,325 lenses have been counted in one of them. As each of these crystalline lenses possesses all the properties of a perfect eye, some butterflies may therefore be said to have no fewer than 34,650 ! The simple eyes, in the form of pellucid spots, are usually two in number, and placed on the crown of the head.

The antennæ are of moderate length, and consist of a great number of joints, which usually increase in thickness towards the extremity, where they form a club or knob.

The thorax-that portion of the body intermediate between the head and abdomenis composed of three segments, so closely united as apparently to form a single piece. The thorax is always shorter than the abdomen, and generally more robust, as it supports all the organs of motion, and contains the muscles by which the latter are actuated.

These important appendages are of course the wings and legs; the latter, as in all other genuine insects, are six in number, and composed of the same amount of pieces as in most of the class. They are inserted pretty close to each other, without any inequality in the size of the intervening spaces. The thigh is often fringed with long hairs, and the tibia is frequently armed with a spur near the middle, and two others at the tip. The tarsi in all the perfect legs are five-jointed, and furnished with two claws at the extremity, which are often bifid. Many of these insects, however, have 
the anterior pair of legs imperfect, or not adapted for walking, being too short to reach the plane of position, and usually drawn close to the sides of the thorax, the long hairs of which in a great measure conceal them from our view. These spurious legs have only one joint in the tarsus, which in some cases is without claws; and the species so circumstanced are named tetrapod, or four-footed butterflies.

The wings are of much greater extent, in proportion to the size of the body, than in any other tribe of insects. The forms which they assume are very various; but the most ordinary shape of the upper pair is triangular, while the outline of the under wings approaches to circular. They are traversed by numerous nervures, which give a great degree of strength to the wing, and hold in tension the thin elastic membrane of which it is composed.

With such an extent of sail broad-vans, it is easy for butterflies to support themselves for a long time in the air. They seldom fly in a direct line, but advance by rising and falling alternately, in a succession of zig-zags, up and down, and from side to side. By flying in this manner they are supposed to elude more easily the pursuit of the smaller birds, which often make them a prey.

\section{HELICOPIS GNIDUS.}

No. 1. The wings of the Helicopis Gnidus are white on both sides, with a slight tinge of yellow at the base, and the outer margin black. At the hinder extremity of the secondary wings there is a row of narrow white marks, which is double at the anal angle; tails black on both sides, the two longest ones tipped with white. The upper wings beneath have a white line dividing the black border behind the middle; and the under pair are ornamented with twenty-one silvery spots, three of which at either extremity are elongated and placed on a white ground, while the rest are insulated, and on a ferruginous ground; all of them edged with black.

\section{THAIS MEDESICASTE.}

No. 2. All the species of the genus Thais are of moderate size, and may at once be known by the peculiar design of the coloring of the wings, which are always yellow, spotted with red and black, and bordered externally with a dark festooned line. The palpi are composed of three nearly equal articulations, and rise conspicuously above the head; the antennæ rather short, and terminating in a club slightly curved upwards. The body is slender, and the abdominal margin of the hinder pair of wings is curved downwards, as if to leave room for the movements of the abdomen.

\section{LEPTOCIRCUS CURIUS.}

No. 3. In this genus the head and body are very thick; abdomen short; eyes large and salient; palpi very short, the articulations very indistinct; antennæ rather long, thickening at the extremity into a club, which is slightly curved upwards. The anterior wings are nearly hyaline, and have the discoidal cell closed; the posterior folded longitudinally, and each drawn out into a very long tail, curved at the extremity. The expansion of the wings, in the only known species, is about an inch and a-half; the inner half of the superior pair black, traversed in the middle by a pretty broad green band; 
the exterior portion, consisting of a large triangular space, transparent, with the nervures and external border black. The inferior wings are black, edged externally with white, and having a central blue band in continuation of the anterior one. On the under side, the base of all the wings is whitish, and the abdominal margin of the under pair is marked with three curved white streaks; abdomen whitish beneath, and having a double row of black dots on each side. In the female the bands on the wings are white.

\section{PEACOCK'S EYE.}

VANESSA YO.

No. 4. The color of this elegant insect is deep brown-ash-red, inclining to purple, with a large eye-like spot on each wing. On the anterior wings this spot is placed near the apex, and is composed of a yellow crescent on the inner side, a semi-circular patch of blue externally, and a large reddish-brown pupil, which becomes darker anteriorly, where it unites with the black margin. On the outer side of the pupil there are three small spots of a whitish-blue color, forming an irregular line with two others placed in the red portion of the wing. The ocellus is bounded internally by a triangular patch of black, next to this is a yellow spot, succeeded by a black triangular one, which does not reach the anterior margin; the latter towards the base is yellowish, with transverse lines of black. The ocellus of the hinder wings consists of a large black central patch, spotted with blue, and encircled by a zone of pale silky-brown, which is bounded anteriorly by a large black crescent.

\section{ERYCINA MELIBAUS.}

Nos. $5 \& 6$. This beautiful insect belongs to that division of Erycina which has opaque wings, and a short obtuse tail to the hinder pair. It is about two inches in extent of wing. The surface is uniform dark brown, with a bright red oblique band running across the middle of both wings, and a large crescent of the same color near the origin of the tail. On the inner side of the upper wings there is the appearance of another oblique red band, but it is obsolete except at the hinder margin. The under side forms a striking contrast with the surface, the ground color being black, with two brilliant blue bands, the outer one very broad, the interior somewhat macular, and terminating behind in a red point. Body brown above and black beneath.

Like most of the species constituting the genus Erycina it is a native of America.

\section{POHYOMMATUS ALEXIS.}

\section{COMMON BLUE BUTTERFLY.}

Nos. $7 \& 8$. This species is so variable in its markings, and even in the form of the wings, that some entomologists are of opinion that more than one distinct species may be included under the name. It is a very abundant insect, and, unlike the rest of its associates, is distributed over the whole country. It frequents pasture lands and grassy meadows. 


\section{THE DAHLIA.}

\section{BOTANICAL DESCRIPTION.}

\section{Class. \\ SYNGENESIA SUPERFLUA. \\ Natural Order. \\ Order. \\ ASTERIOIDÆ. \\ COMPOSIT 压.}

Generic Character-Head radiated, flowers of the ray ligulate, female or neuter, those of the disk tubular, five-toothed. Involacre double. Receptacle flat, chaffy, scales membraneous, oblong, undivided. Branches of the style erect or somewhat incurved, thick, externally hairy. Anthers exudate appendiculate.

Specific Character-Leaves opposite, divided in a pinnate, more rarely in a bi-pinnate manner. Segments ovate. Roots fasciculate, some cylindrical, others oblong, tuberculate. Branches elongated at the apex naked, one-headed. Heads various in color.

The Dahlia, although a plant of this continent, being originally from Mexico, was known in Europe before it was cultivated in the United States. It is generally said to have been introduced into England by Lady Holland, in 1804; but the fact is, it had been introduced there many years before that period, and was only brought from Madrid, in 1804, by Lady Holland, who apparently did not know that it was already in the country. The first kind of Dahlia known to Europeans was discovered in Mexico by Baron Humboldt, in 1789, and sent by him to Professor Cavanilles, of the Botanical Garden, at Madrid, who gave the genus the name of Dahlia, in honor of the Swedish Professor Dahl. Cavanilles sent a plant of it the same year to the Marchioness of Bute, who was very fond of flowers, and kept it in the green-house. From this species nearly all the varieties known in the gardens have been raised; as it seeds freely, and varies very much when raised from seed. It is rather remarkable that the Dahlia Superflua, or Variabilis, should produce flowers of colors so different, as crimson, purple, white, yellow, orange and scarlet. Among all the colors, however, displayed by these varieties, no flowers have yet appeared of blue, and comparatively few of a pure white.

The Dahlia is a tuberous-rooted plant, which is propagated either by seeds or division of the root. The seeds are chiefly used for raising new sorts; and they should be treated like tender animals, being sown on a slight hot-bed in March or April, and planted out in May, or the beginning of June, according to the season. The plants rarely flower the first year, but the tubes will form in the course of the summer, and may be taken up in autumn with those of the old plants. When the plants are propagated by division of the root, care must be taken that each piece has a bud to it. These 
buds, or eyes, as the gardeners call them, are not scattered all over the tuber, like those of the potato, but collected in a ring round the collar of the root. The eyes, when the root is in a dry state, are sometimes scarcely perceptible; and to discover them, Aurserymen often plant their roots in a hot-bed, "to start the eyes," as they call it ; that ls to say, to force the latent buds sufficiently forward to show where they are situated, before they divide the roots for the purpose of forming new plants.

Dahlias are also propagated by cuttings of the stem, taken from the plant; or young shoots slipped off the tuber, with part of the woody fibre, attached. The cuttings should be stuck in sand, or very sandy loam, under a bell glass, and with bottom heat. Great care should be taken to shield them from the direct rays of the sun, till they have thrown out roots, as the leaves are easily withered, and when this is the case, they cannot be recovered; and the cuttings will perish, for want of due circulation of the sap. The roots will generally form in a fortnight, or at most three weeks.

The best soil for Dahlias is a compost of equal parts of sand and loam, with a little peat; which may be enriched with part of an old hot-bed, or decayed leaves. Manure of any kind should, however, be used very sparingly; as too much will cause the plant to produce strong, coarse-growing leaves and stems, instead of fine flowers. Though they flower so late in the year, Dahlias are killed by the slightest frost; and thus their beauty, great as it is, is generally rather short lived. As soon as the leaves turn brown from frost, the stems should be cut down, and in about a month after, the tubers should be carefully taken up, and laid on boards in open shed, or some similar place, where they are protected from the rain and sun, but still have plenty of air. They should afterwards be kept in a dry cellar, in sand or sawdust.

The beauty of the Dahlia is estimated principally by the shape of the flower, which should be perfectly circular, without any of the petals projecting beyond the others.The size and color of the flowers are considered as of inferior consequence to the form, by professed florists; though, of course, large flowers are generally preferred to small ones.

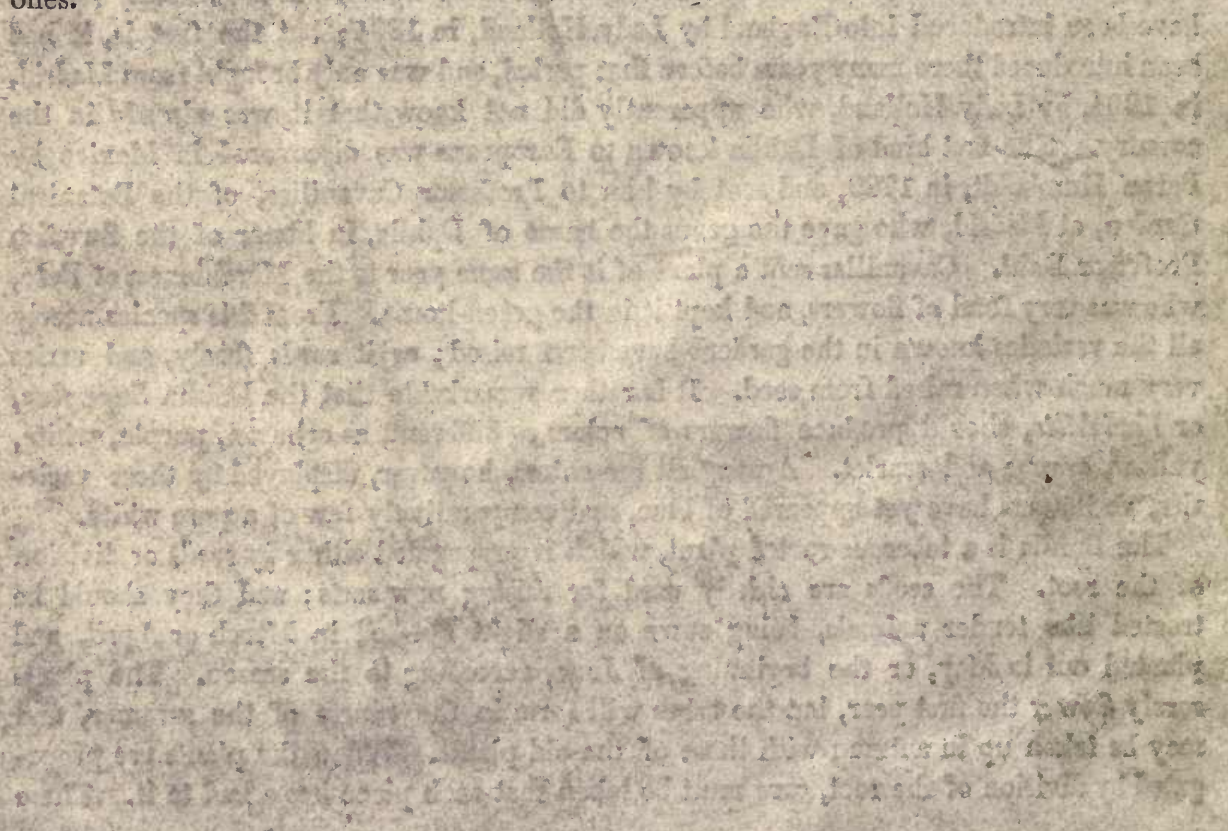




\section{after-}

ies, which for the others. wsequence to the form, Hy preferred to small

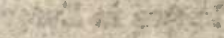

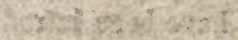

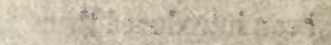

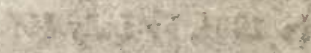

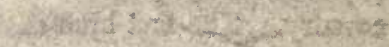

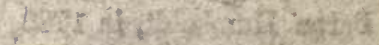

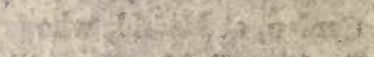
ais

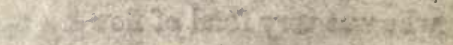

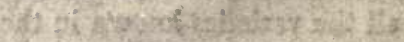

(1)

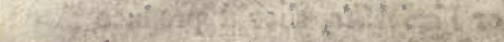

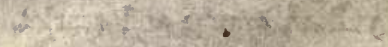
(x) Sist

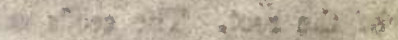

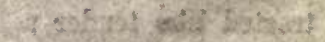

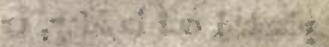

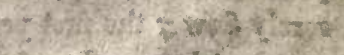

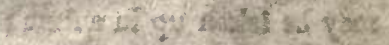
(2) 3a als be in 
CASE 


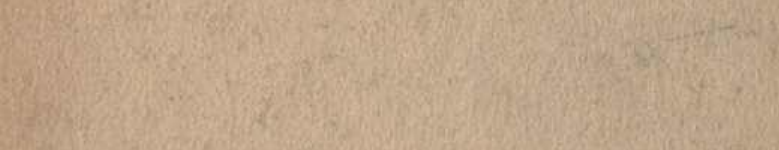

